\title{
Identity and Interpretation of Public Artworks: A Challenge to Intentionalism
}

KEY WORDS

art, public artwork, intentionalism, identity

\begin{abstract}
Baldini Andrea, Identity and Interpretation of Public Artworks: A Challenge to Intentionalism [Tożsamość oraz interpretacja publicznych dzief sztuki: wyzwanie dla intencjonalizmu]. Kultura - Społeczeństwo - Edukacja nr 2(8) 2015, Poznań 2015, pp. 9-26, Adam Mickiewicz University Press. ISBN 978-83-232-3004-5. ISSN 2300-0422
\end{abstract}

This paper explores whether MT and IT apply to public artworks. In particular, it discusses whether a public artwork can acquire through time a property that cannot possibly accord with the artist's intentions, and consequently, whether an interpretation that attributes that "new" property to that public artwork can be legitimate. It also clarifies when an artwork is public and introduces the example of a public artwork that seems to have acquired a property at odds with the artist's intentions. It discusses and argues that Carroll's intentionalist account of conversation is insufficient. Conversations, like public artworks, possess perlocutionary features that, at least sometimes, cannot be explained on intentionalist grounds.

\section{Introduction}

Noel Carroll's modest actual intentionalism (MAI) argues for (at least) the two following theses about the artist's intentions (Carroll, 1992: 97-131) Call the first one metaphysical thesis (MT): the artist's intentions are relevant to fixing the artistically salient properties that an artwork has, that is, its identity (Carroll, 1995: 257.). Call the second one interpretational thesis (IT): the artist's intentions are relevant to constraining an artwork's possible interpretation(s) (Carroll, 1997: 305). 
As a consequence of MT, an artwork cannot acquire through time an artistically salient property that exceeds the expected possibilities that an artist could have intended (e.g., an "anachronistic" stylistic property). In effect, Carroll says, to admit a change in an artwork's properties would entail to accept the possibility of backward causation - a "commitment" that seems "problematic in and of itself" (Carroll, 1995: 256).

And as a consequence of IT, one cannot consider as legitimate those interpretations imputing "newly acquired" properties that cannot be possibly reconciled with the artist's intentions. In Carroll's view, those are, at best, metaphorical and heuristic discourses that are psychologically valuable, and that do not play any "probative" function in determining the "real properties of artworks" (Carroll, 1995: 257).

This paper explores whether MT and IT apply to public artworks. In particular, it discusses whether a public artwork can acquire through time a property that cannot possibly accord with the artist's intentions, and consequently, whether an interpretation that attributes that "new" property to that public artwork can be legitimate. Contra MAI, I argue that, as a consequence of a change in its context of reception, a public artwork can acquire a property that the artist could not have foreseen. I also suggest that interpretations at odds with the artist's intentions can be legitimate. Therefore, I hold that MT and IT do not apply to public artworks.

I develop my argument by discussing Carroll's original defense of MAI. There, Carroll develops an argument from analogy that I call "conversational hypothesis" (CH). CH argues that, when engaging an artwork, we enter a relationship with the artist that is "roughly analogous" to having a conversation with her (Carroll, 1992: 117). I accept CH as instructive. ${ }^{1}$ However, by drawing on recent developments in linguistic anthropology and conversational analysis, I argue that the intentionalist account of conversation falls short when considering perlocutionary acts and their effects. Analogically, intentionalism does not have the resources to explain what I call a public artwork's perlocutionary properties.

Before continuing, let me make explicit why I focus on public art. First, I choose public art since I believe that no artistic practice is actively shaping our

\footnotetext{
${ }^{1}$ Some philosophers challenge intentionalism on the basis, among other things, of the inadequacy of the conversational model. See: Davies, 2006: 223-247; Dickie, 2006: 70-81; Margolis, 2010; Wilson, 1997: 309-311.
} 
world as that art form is doing. For instance, a decision in public art matters can result in an action that could change forever the plaza where one lives, or the street where one has her office. Second, as a public phenomenon, public art is at odds with dominant aesthetic theories, which sees art as "the product of an individual and autonomous act of expression, and its appreciation [as], likewise, a private act of contemplation" (Hein, 1996: 1). As such, it help us consider new possibilities in terms of aesthetics inquiries.

Section 2 clarifies when an artwork is public and introduces the example of a public artwork that seems to have acquired a property at odds with the artist's intentions. Section 3 discusses $\mathrm{CH}$, and argues that Carroll's intentionalist account of conversation is insufficient. Conversations, like public artworks, possess perlocutionary features that, at least sometimes, cannot be explained on intentionalist grounds. Section 4 discusses a possible objection to my account.

\section{Removing a Public Artwork: Silva's Rock Steady Gravity Sketch}

Realized by Brazilian artist Artur Silva, Rock Steady Gravity Sketch is a sculpture that was installed outside The Avenue apartments building, near 10th Street and Indiana Avenue in Indianapolis, IN. ${ }^{2}$ It was inaugurated on Friday, August 24, 2012. Sized $6^{\prime} 7^{\prime \prime} \times 6^{\prime} 2^{\prime \prime}$, the sculpture is in aluminum and vinyl on steel with internal LED lights. It represents in full-scale an African American "b-boy" that is, a male breakdancer - wearing blue pants and a bright yellow long sleeve shirt. The b-boy is represented in the act of performing a particular dance move called "handstand." When performing the handstand, a dancer stands on his hands with his feet in the air. With his piece, Silva intended to celebrate publicly African-American culture. In particular, Silva's desire was to connect two fundamental achievements in African-American history, that is, the Jazz Age and the hip-hop "revolution." Such a connection was made possible by the nature of the location where the piece was installed. During the Jazz Age (1920s), the area around Indiana Avenue was a center of African American night life (Taflinger, 2012).

\footnotetext{
${ }^{2}$ See $<$ http://artursilva.com/section/318204_Rock_Steady_Gravity_Sketch.html $>$.
} 
Silva's Rock Steady is a public artwork. By following a dominant strand in the studies of public art, one can characterize public artworks (whose extension includes, though not exclusively, things like monuments, memorials, public sculptures, and so on) in terms of their context of reception. ${ }^{3}$ In effect, when we consider non-public artworks, their reception takes place within a specific context, the artworld, whose features are generally determined by art historical considerations. On the contrary, public artworks are received primarily within a more general and unspecialized context. Public artworks are in fact received within a "public sphere." 4 Public art scholarship borrows the notion of a public sphere from the work of German philosopher Jürgen Habermas. ${ }^{5}$ By drawing on Habermas' view, we can characterize a public sphere as the discursive space constituted by private individuals debating rationally (or perhaps reasonably) issues related to the public good. ${ }^{6}$

By drawing on Michael Warner's work on public and counter-publics, Jennifer Mikulay suggests that public art addresses and constitutes multiple publics rather than a single and overarching unity (see Warner, 2002: 49-90). The publics of public art, Mikulay writes, are "best not reduced to 'the public,' 'the community,' or 'the audience."' (Mikulay, 2011: 5-23). In this sense, one could also add that public artworks are not received within a public sphere, but within different public spheres. ${ }^{7}$ Those public spheres are the multiple discursive spaces where different publics debate issues related to the presentation of distinct public artworks.

As Arthur Danto and Harriet Senie independently argue, when discussing artworks in a public sphere, aesthetic concerns are irrelevant (Danto, 1998: 147151; Senie, 1992: 173). Political, social, and economic issues related to the public good are the focus of those discussions. In fact, discussions about public artworks build up around questions such as "How does the public artwork relate to the identity of its site and relative communities?", "Does it suit the identity of

\footnotetext{
${ }^{3}$ See, for instance, Knight, Senie, 2012: 1-2.

${ }^{4}$ See, for instance, Mitchell, 1992a: 1-5; Mitchell, 1992b: 29-48; Senie, 2002: 102-103; Knight, 2008; Zuidervaart, 2011).

${ }^{5}$ See Habermas, 1989. The original version, published in German, is an adaptation from Habermas' Habilitationsschrifts at the University of Marburg. See Habermas, 1962.

${ }^{6}$ As many theorists suggest, Habermas' conception of rationality is too narrow for capturing the logic of public discourse. In particular, it seems incapable of understanding the role emotions. See, among others, Gardiner, 2004: 28-48.

${ }^{7}$ See, for instance, Rospocher, 2012: 9-28; Eager et al (eds.), 2001; Eager, 2001; Landes, 1988.
} 
those communities?", "Was the monetary budget appropriate?", "Was the budget well administered?", "Does the public artwork have a negative environmental impact?", and other questions directly related to a relevant issue explicitly addressed by the content of the artwork. ${ }^{8}$ One should emphasize that those questions address actual issues that interest the members of a public artwork's public, and answers to those questions are meant to have practical consequences.

By appreciating the preceding, one should emphasize that art historical considerations do not have priority in determining the features of a public artwork's context of reception. In effect, because of the intimate relationship that connects a public artwork to its public(s), the features of a public artwork's context of reception (a public sphere) are much more likely to be determined by the history(-ies) of those who participate in its discussions, that is, the members of its public(s). In this sense, the features of a public artwork's context of reception are not generally determined by art historical considerations, but rather (though not exclusively) by considerations of the history of that artwork's public(s).

With these notions in mind, let me go back to Rock Steady. Unfortunately, a few days after the installation of Rock Steady, on September 3, a tragic event occurred. A Purdue University freshman, Xavier Somerville, fell from a fifth-floor balcony trying to evade police during a rowdy party, and died in the proximity of Silva's statue. In the aftermath of this event, some have started recognizing a close resemblance between the dancer represented in Rock Steady and a young man falling. Because of this possible resemblance, some started to question whether it was appropriate to keep the statue in its original location. Some believed that it was not appropriate, and asked for the relocation of Silva's work. ${ }^{10}$

\footnotetext{
${ }^{8}$ Questions of monetary budget were at the core of the debates generated respectively by Noguchi's Landscape of Time (1977) and Michael Heizer's Adjacent, Against, Upon (1977). Questions of identitarian appropriateness were fundamental in the debates generated by Pablo Picasso's Untitled (1967), also referred to as "Chicago Picasso," and Robert Graham's Monument to Joe Louis (1986). Questions of environmental sustainability are, among others, the critical focus of the still on-going debate generated by Pino Castagna's In pietra alpestra e dura (2009). Questions about the issues related to the Vietnam War and its consequences on veterans were and still are the very focus of the reception of Maya Lin's Vietnam Veterans Memorial Wall (1982). Other socially relevant issues that have been addressed explicitly by public artworks include women's and minorities' rights, HIV/AIDS research and care, and environmental awareness.

${ }^{9}$ See AA.VV. "Storm Over Statue Highlights Angst Over Indy Art," (October 6, 2012) <http:// www.courierpress.com/news/2012/oct/06/storm-over-statue-highlights-angst-over-indy-art/>.

${ }^{10}$ In a private conversation, Arthur Silva suggested me that journalists from FOX news were instrumental in creating the controversy.
} 
Others opposed that proposal by pointing to the fact that all the evidence we have indicated that Arthur Silva did not have the intention to make his statue as resembling a young man falling. Those opposing relocation believed that the interpretation invoked by those asking for removal was incorrect, and argued that one should not remove the artwork on the basis of such a mistaken reading. When asked about his opinion on the proposal of removing the statue, Bryan Cahen, a retired art administrator living in Indianapolis, replied quite colorfully that its resembling a young man falling was an "idiotic reason to remove a piece of artwork [sic]."11

After a few weeks of harsh controversy, the proposal to relocate the statue prevailed, and Rock Steady has been removed from its original location since then. But were those opposing Rock Steady's relocation correct? Was the interpretation attributing "resembling a young man falling" to Silva's statue unwarranted? Was that resemblance a mere psychological association, or did it belong to the real properties of Rock Steady's properties? And more generally, do artistic intentions constrain the identity and interpretation of public artworks?

In the following section, I consider the previous questions. I suggest that "resembling a young man falling" should be considered as a perlocutionary property of Rock Steady. Perlocutionary properties are among the real properties of an artwork, and partly determine its meaning. Artworks' perlocutionary properties are analogous to the perlocutionary acts that one performs in a conversation. Since one cannot fully explain conversations' perlocutionary acts in terms of the speaker's intentions, I argue that the same holds for artworks' perlocutionary properties. In this sense, there are plausible grounds for considering "resembling a young man falling" as among Rock Steady's properties, and the interpretation attributing that property to the statue as legitimate. As a further consequence, I also contend that the proposal to relocate Rock Steady was not unreasonable. More in general, I suggest that MT and IT do not (strictly) apply when considering public artworks.

Before continuing I want to emphasize that I remain neutral about whether removing Silva's statue was the optimal choice. This paper does not pick a side in the controversy. Its aim is to unpack those philosophical complications that emerge when considering Rock Steady's controversial case. ${ }^{12}$

\footnotetext{
11 "Storm Over Statue Highlights Angst Over Indy Art."

${ }^{12}$ At the IAS meeting in Krakow, where an earlier version of this paper was presented, some participants suggested - I believe correctly - that my model would support an argument against Rock Steady's
} 


\section{Intentions, Conversations, and Perlocutions}

In How to Do Things with Words, Austin argues that a fundamental aspect of the "meaning" of an expression is what it is used to do, that is, what kind of act(ion) one performs when one says something (Austin, 1962). What kind of act(ion) one performs when one says something is the speech act aspect of language. Austin distinguishes between three kinds (or levels) of speech acts: locutionary acts, illocutionary acts, and perlocutionary acts. First, a locutionary act is the performance of a basic linguistic action of uttering sounds that have meaning or definite reference. ${ }^{13}$ Second, an illocutionary act is the act of determining "in what way we are using" a locutionary act (Austin, 1962: 98). In other words, the illocutionary act specifies the act that one is performing in saying something such as asking or answering a question, giving an assurance or a warning, making an appeal or a criticism. (Those are only a few examples of this kind of speech acts.) (Austin, 1962: 102). Third, a perlocutionary act is the act of bringing about specific effects on the feelings, thoughts, or behavior of the hearers, for example, persuading or convincing someone to do something. Call perlocutionary effect as the effect of generating particular consequences on the feelings, attitudes, and subsequent behavior of the hearers such as "being convinced that," "being persuaded that," „being surprised that," or "being mislead that."

Carroll believes that illocutionary acts consist characteristically in uttering words in sentences with certain intentions, and illocutionary effects are always produced as a consequence of particular (intentional) illocutionary acts. In this sense, he argues that the meaning of an illocutionary act depends on and can be interpreted by means of the speaker's intention. In a conversation, Carroll writes, "the meaning of an utterance is explicated in terms of the speaker's intention to reveal to an auditor that the speaker intends the auditor to respond in a certain way." (Carroll, 1992: 97).

Many would agree that Carroll (and intentionalists in general) is correct about illocutionary acts. ${ }^{14}$ However, normal (and perhaps one could say mean-

removal. By resembling a young man falling, Silva's statue could be thought as a way to honor Somerville's memory.

${ }^{13}$ Austin further distinguishes between three kinds of locutionary acts: phonetic acts, which are mere emissions of noises; phatic acts, which are utterances of grammatical sentences; and rhetic acts, which utterances of a sentence with a definite sense and reference. Austin writes that the "pheme is a unit of language [but] the rheme is a unit of speech" (Austin, 1962: 98).

${ }^{14}$ Carroll's account comes directly from Grice's account of meaning, which is widely accepted in philosophy of language. See Grice, 1957: 377-388; Grice, 1968: 225-242. However, Duranti challenges the view that a distinction between illocutionary and perlocutionary aspects can be applied to utterances in real-life conversations. He suggests that, in many cases, whether an utterance $p$ is an illocutionary act 
ingful) conversations include also perlocutionary acts and effects. (I start a conversation with you because I want to convince you not to ask for a divorce.) But, as Alessandro Duranti suggests, intentionalism's shortcomings clearly appear when trying to explain the perlocutionary dimension that normally characterizes conversations (Duranti, 1993: 14).

For instance, I can promise you that $p$ by merely saying "I am promising you that $p$, and, plausibly, the meaning of my utterance is determined by my intention to promise you that $p$. But I cannot convince you that $p$ by merely telling you: "I am convincing you that $p$. " (After our conversation, you could still want a divorce.) Whether my attempt to convince you that $p$ is successful depends on how you respond to my words, not on my intention to do so. And, plausibly, by trying to convince you that $p$, my words may very well have the unintentional effect of convincing you that non-p. (Perhaps, my words convinced you even more that you want a divorce!)

Then, if not in terms of the speaker's intention, how should we explain the perlocutionary dimension of a conversation, with particular reference to its perlocutionary effects? By drawing on linguistic anthropology, ${ }^{15}$ interactionist approaches to the study of language, ${ }^{16}$ and empirical researches in the social sciences (Bourdieu, 1977; Kochman, 1983: 329-337; Schegloff, Sacks, 1973: 289327; Streek, 1980: 133-154). I propose an answer that echoes "hermeneutic" approaches to interpretation such as one can find in thinkers like Bakhtin, Gadamer, and Wittgenstein (Bakhtin, 1981; Gadamer, 1976; Wittgenstein, 1953). Rather than in terms of the speaker's intention, one could better explain perlocutionary effects in terms of socially available criteria, which one might also call as "grammatical rules" or "local norms" (Duranti, 2009: 14).

One cannot determine a priori which criteria apply in interpreting the perlocutionary aspects of real-life conversation (Duranti, 1986: 241). Criteria are implicitly negotiated by those conversing while conversing. Conversations are, I believe, similar to those games where we "make up the rules as we go along." 17

\footnotetext{
of a particular type is partly determined by how the audience reacts. However, here I do not discuss this possibility. See, for instance, Duranti, 1993: 26.

${ }^{15}$ For a introduction to Linguistic Anthropology, see Duranti, 2005. For a useful overview of the field and its debates, see Duranti, 2009. See also Duranti, 1986: 239-247.

${ }^{16}$ See, among others, Goodwin, 1981.

${ }^{17}$ At $\$ 83$ of the Philosophical Investigations, Wittgenstein writes: "And is there not also the case where we play and - make up the rules as we go along? And there is one where we alter them - as we go along."
} 
Such a selection is significantly influenced by "the dynamics between the speaker's words and the ensuing circumstances (audience's response included)" (Duranti, 1986: 241). As Duranti puts it:

interpretations [of perlocutionary effects are] defined by the kind of norms and social world that the participants in the interaction are able to evoke at a given time and place. Furthermore, there are many cases in daily life in which the meaning of a given act is not defined until the recipient of that act has replied. ${ }^{18}$

In order to clarify this point, I should add few remarks. I am arguing that perlocutionary effects of conversations and their interpretations cannot be explained solely in terms of the speaker's intention. They are primarily explained in terms of contextual considerations about the larger socio-historical setting within which the conversation is taking place, the relations between the speaker and the audience, and the psychological dispositions of the interlocutors. ${ }^{19}$ Those considerations concur significantly to determine what kind of perlocutionary effects an utterance brings about.

In this sense, one should not rule out the possibility that uttering in different contexts - where different "local" norms are at play - the very same words with the same intention (that is, the same locutionary and illocutionary acts) may very well generate very different perlocutionary effects. Thus, one cannot fully determine the "meaning" of utterances in a conversation, in particular with respect to their perlocutionary effects, in terms of a speaker's intention. As a consequence, when considering conversations, their interpretation cannot be constrained by the speaker's intention.

I should also emphasize the following crucial point. The context of a conversation is not a "static container" for utterances. It is dynamic and receptive, and cannot be determined and known by interlocutors before the conversation starts, neither under idealized conditions. Moreover, context is continually produced

\footnotetext{
${ }^{18}$ Ivi. Emphasis added.

${ }^{19}$ Here, I want to emphasize a point. I have a sense that both Gadamer's and Wittgenstein's theory of interpretation generally focus on "intersubjective" (e.g., socio-historical and interactional) aspects, while often overlooking the importance of psychological dispositions as important contextual elements. I find Bakhtin's view more accurate in this regard. He writes: "In the actual life of speech, every concrete act of understanding ... assimilates the word to be understood into its own conceptual system filled with specific objects and emotional expressions... $[P]$ rimacy belongs to the response as the activating principle: it creates the ground for understanding." (Bakhtin, 1981: 282. Emphasis in the original).
} 
through the same conversational interactions. ${ }^{20}$ It is influenced by what is uttered when uttered, and conversational interactions continually redefine it. ${ }^{21}$

Consider the following example. My friend Gino used to tell a (supposedly) true story of a poorly performed "party trick" at a wedding ceremony. According to the story, a wedding guest opens a bottle of champagne with a saber. The guest does not control the just broken neck of the bottle, which flies across the room and hits the bride in her left eye. The story, and the way Gino was able to tell it, used to generate humorous laughs among those who heard it. (I must admit that I found it somewhat cruel, but nonetheless funny.) With the same intention of generating laugh, Gino told the story one more time. However, he told the story to a man whose bride underwent a similar accident. Of course, this man reacted with visible distress rather than with laughter.

One could interpret that conversation as follows. The context within which the interaction between Gino and this man took place changed, in a way that cannot be explained in terms of Gino's intention, some properties of his utterances. In particular, it changed the nature of some of its perlocutionary acts, which became acts of mocking, disrespecting, and insulting rather than of bantering. Those perlocutionary acts had the (unintended) perlocutionary effect of distress in Gino's interlocutor. (That night, Gino felt as embarrassed as one could imagine, and apologized sincerely to the man and his wife. He never told that story again. $)^{22}$

By appreciating the preceding, I argue that public artworks are analogous to conversations, but to conversations that include perlocutionary acts - as virtually every real-life conversation does. In this sense, like utterances, public artworks possess (sometimes intentionally) what some philosophers call "perlocutionary

${ }^{20}$ This thesis is also at the core of Paul Dourish's work on information theory in Where the Action Is: The Foundations of Embodied Interaction (Cambridge, MA: MIT Press, 2001).

${ }^{21}$ See Duranti, 2012: 12-23. Context has been re-examined along these lines in Duranti, Goodwin, 1992.

${ }^{22}$ One cannot dismiss this example by suggesting that this is a case of "failed communication," and that in cases of successful communication perlocutionary effects comply with those intended. In effect, if one would be willing to define all those cases where unintended perlocutionary effects obtain as cases of failed communication, one should also maintain that most cases (perhaps virtually all cases) of human communication are cases of failed communication. It seems to me obvious that, most of the times, our words generate unintended reactions. For instance, since in virtually every philosophical conversation not all the participants are convinced by the same claims, then philosophical conversations would be examples of failed communication. I take this consequence as a reductio ad absurdum of this objection. 
properties," that is, "potentials for performing acts and achieving effects". ${ }^{23}$ In suggesting that public artworks have perlocutionary properties, I am drawing on works by David Goldblatt and Arthur Danto. Goldblatt argues that what I define as an artwork's perlocutionary properties are sometimes "integral to the meaning of the work" (Goldblatt, 2011.) "On his part, Danto writes that public artworks are perlocutionary since they "do more than convey information" (Danto, 1998: 149).

As I have argued in the case of perlocutionary effects, the perlocutionary properties that a public artwork has cannot be explained in terms of the artist's intention. In effect, perlocutionary properties and, a fortiori, a public artwork's identity are determined significantly by considerations of the context within which the metaphorical conversation between an artist and members of its public(s) obtains. The features of that context of conversation are determined by a number of factors, including the interaction among members of the artwork's public(s), their collective history(-ies), and so on. Changes in those factors may very well modify the perlocutionary aspects of an artist's "utterance," that is, of her artwork. Thus, if a public artwork can have properties that do not comply with the artist's intention, then a public artwork's interpretation cannot be constrained by that intention. In this sense, MT and IT as developed by MAI do not apply in the case of public artworks.

Let us reconsider by means of the conceptual resources developed in this section Rock Steady's case. One could assume that the original context within which the metaphorical conversation between Silva and members of Rock Steady's public(s) evoked a social world and local norms such that the perlocutionary acts and effects that the sculpture engendered matched those intended by the author. However, a relevant change in that context, that is, Somerville's tragic death, modified the social world and the norms that the conversation between Silva and the members of Rock Steady's public(s) could evoke. As a consequence of that change, Silva's "utterance," that is, Rock Steady, acquired the perlocutionary property of "bringing to mind the forms of someone's falling." According to the local norms that the context evoked, some found the likeness suggested by the image as inappropriate and, as a perlocutionary effect, experienced a feeling of discomfort.

${ }^{23}$ M. Richard, When Truth Gives Out (Oxford, UK and New York, NY: Oxford University Press, 2008,12 ). David Davies uses the term "perlocutionary property" when discussing artworks. See Davies, 2004: 91 . 
I should emphasize that the above discussion of how Rock Steady acquired the new property "resembling a young man falling" follows analogically the rather un-controversial idea that the same words uttered in different contexts may very well mean different things, and may very well generate justified diverging reactions in those participating in the conversation. Of course, intentionalists might object that one should "freeze" the context within which the conversation between an artist and members of its public(s) takes place, while maintaining that only contextual considerations relative to the moment when the artwork was firstly presented are acceptable. One could answer intentionalists that what they are describing, then, is not a conversation. In this sense, they cannot defend their views in terms of a conversationalist model. The burden of the proof is theirs.

\section{An Objection Considered: Meaning and Significance}

At this point, Carroll could defend his view by claiming that my argument about perlocutionary properties is not a threat to intentionalism. In effect, he could suggest that my argument is concerned with what one might call Rock Steady's significance, and not with its meaning. Hirsch first introduced such a distinction. ${ }^{24}$ According to that distinction, meaning is "what the author meant by his use of a particular sign sequence, it is what the sign represents" (Hirsch, 1966: 8). By being determined by the artist's intention, meaning is fixed and immutable. Significance, on the contrary depends on the present use of the artwork, and is therefore changeable. In effect, significance "names a relationship between that meaning and a person, or a conception, or a situation, or indeed anything imaginable" (Hirsch, 1966: 8). Whereas meaning is the "exclusive object" of interpretation, significance "is the proper object of criticism" (Hirsch, 1966: 57).

In "Artworks and the Future," Jerrold Levinson uses Hirsch's distinction between meaning and significance in order to deny that the real properties of an artwork can change over time (Levinson, 2011: 210 and ff). Meaning, Levinson argues, has to do with what he calls the "content" of an artwork, which includes its "aesthetics properties..., artistic properties..., representational properties, and

\footnotetext{
${ }^{24}$ See Hirsch, 1960: 463-479; Hirsch, 1966; Hirsch, 1984: 202-225. The distinction appears extensively in the intentionalist literature. See, among others, Carrol, 1995; Levinson, 2011: 179-214; and, Stecker, 1994: 193-206.
} 
meaning properties." (Levinson, 2011: 182). Significance captures instead all those relational features that are „outside the sphere of proper understanding of [an] artwork" (Levinson, 2011: 190). In other words, according to Levinson, when we speak about an artwork's significance, we refer to those "salient similarities, echoes, or parallelism discernible between the given work and the external matter with which it is brought into comparative relation" (Levinson, 2011: 190). And yet, those relations do not posses a constitutive function, and do not modify the content of the artwork, that is, its meaning.

Carroll could then say that "resembling a young man falling" is part of Rock Steady's significance, but not of its meaning. Accordingly, his view could accommodate the perceived resemblance between Silva's statue and a young man falling while denying that "resembling a young man falling" is a real property of Rock Steady. In this sense, Carroll could allow the critical discourse that sees the sculpture as echoing the death of Somerville without undermining MT or IT. In brief, on the light of this distinction, Carroll could conclude, MAI seems to apply to public art as well.

There are at least two ways to meet the potential challenge discussed in above. The first response is to bite the bullet and accept that "resembling a young man falling" is part of Rock Steady's significance, and to further press the point by asking what are the practical consequences of introducing such a distinction at the level of public discourse. By considering such a resemblance as part of Rock Steady's significance, would a person be justified in asking for the removal of the statue? Would that request be reasonable once we consider "resembling a young man falling" as an aspect of that sculpture's significance? Hirsch's discussion of meaning and significance, I believe, offers a suitable starting point for answering these questions.

When introducing the analytic distinction between meaning and significance, Hirsch's intent was not to dismiss the relevance of the latter. According to Hirsch, in effect, significance as the object of criticism is more "valuable and useful" than meaning (Hirsch, 1966: 190). "[Significance," he writes, "changeable or not, is the more valuable object of interpretation, because it typically embraces the present use of texts, and present use is present value" (Hirsch, 1984, 203). Therefore, if one accepts Hirsch's point about significance's greater value, then one seems also committed to accept as most valuable the critical assessment according to which Rock Steady evokes the forms of a young man falling. In other words, to say that "resembling a young man falling" belongs to the sculpture's 
significance does not imply the dismissal of those readings that refer to that resemblance. Quite the contrary, it seems to suggest that such a reading is more valuable than an interpretation that depends on the sculpture's meaning, or, at least, that they are both acceptable. In this sense, by considering "resembling a young man falling" as an aspect of Rock Steady's significance, one seems committed to accept as reasonable the request to remove the statue. If my analysis is correct, then, Carroll and I might have reached some sort of agreement. Though still differing in principle, pragmatically both views allow for that open debate that essentially characterizes the appreciation of Rock Steady as public art.

Some might find this pragmatic agreement satisfactory. However, I think that there is a second, and more radical, response to Carroll's possible objection. This second response questions the possibility of fully vindicating the distinction between meaning and significance in public art. As we have seen, such a distinction presupposes that only the context of creation determines the real properties of an artwork. The context of reception, on its part, plays only a secondary role: it merely broadens the possible associations between that artwork and a given cultural milieu that differs from the original one, while not affecting that artwork's identity. This point, I believe, disregards the nature of our appreciation of an artwork as public art and, therefore, should be rejected. In effect, public art is essentially relational: public art, many agree, is art received within the public sphere. It seems to me that confining the context of reception to a secondary role is to neglect this essential feature of public art. In other words, considering the relational properties that emerge as a function of a public artwork's reception as extrinsic to that artwork's nature is to treat it, I believe, as non-public art.

Let me put this point in a slightly different way. According to Hirsch, the object of "historical scholarship" is meaning (Hirsch, 1984: 203). That is, the aim of scholars involved in literary or, one might plausibly add, artistic interpretation is to reconstruct the intentions of the author. As such, an accurate interpretation of a literary text or, more in general, an artwork requires historical knowledge about the creation of those cultural artifacts. Plausibly, this understanding of historical interpretation captures what scholars interested in forms of non-public art do. For instance, as object generally separated from other domains of human life, artworks in museums function primarily as historical testimonies of the creativity of some extraordinary individuals from the past. An accurate interpretation of that type of artworks, one might say, has to do with a rigorous reconstruction of the historical conditions of their respective origin, with particular reference to the author's intentions. 
However, Hirsch's view does not apply to scholarly interpretation of public artworks. In effect, public artworks are not separated from other domains of human life. As I have already suggested, public art intersects with social, political, and economic aspects of our communities. It is a part of our social world: in Danto's words, "it is us, in the medium of artistic transformation" (Danto, 1998: 151). Thus, the relationships between a public artwork, the cultural milieu of its reception, and its public do not exceed the proper understanding of that artwork: those relationships are an essential feature of its nature as public art. In this sense, no accurate scholarly interpretation of a public artwork can ignore the history of its reception. As a living aspect of ongoing public life, there is no principled disjunction between the authorial meaning and the relational significance that a public artwork can acquire over time: those relations are an intrinsic aspect of its nature as public art. ${ }^{25}$ For instance, an interpretation of the Vietnam Veterans Memorial in Washington DC ignoring the controversies that surrounded its installation, which eventually led to the addition of Frederick Hart's The Three Soldiers to Maya Lin's wall, is not an interpretation of it as public art. ${ }^{26}$ Similarly, an interpretation of Rock Steady as public art cannot ignore the controversy surrounding Somerville's death. For this reason, it seems that the distinction between meaning and significance that Hirsch originally developed and many intentionalists accept does not apply. To talk about how an artwork relates to its cultural milieu is necessary in order to interpret it as public art. ${ }^{27}$

Before concluding, I want to add a qualification. The above discussion merely suggests that there is no supreme authority in public art, not even artists themselves - or their intentions. Of course, the claim that the artists' intentions have no supreme authority in determining the properties of a public artwork should not be taken as implying that they have no role whatsoever in those matters. Simply the artist's intentions are not overriding reasons for deciding whether a property belongs to public artwork, and, a fortiori, cannot constrain their interpretations. An accurate interpretation of a public artwork generally exceeds the boundaries set by intentional readings.

\footnotetext{
${ }^{25}$ Glenn Parsons and Allen Calrson raise a similar point when arguing that the nature and function of a plaza may very well change over time in ways that contradict the designer's intention. See Parsons, Carlson, 2008: 64 .

${ }^{26}$ For a sympathetic discussion of the Vietnam Veterans Memorial, see Blair, Jeppeson, Pucci Jr, 1991: 263-288.

${ }^{27}$ Of course, not all opinions about an artwork influence its nature as public art. However, publicly acceptable interpretations generally do it.
} 


\section{Conclusion}

In this paper, I have discussed some aspects of public artworks. I have characterized public artworks as those artworks received within a public sphere, rather then within artworld institutions. I have added that there is a multiplicity of public spheres within which public artworks can be received, and a plurality of publics that those artworks can address. I have suggested that, contrary to what happens in the case of a non-public artwork, the features of a public artwork's context of reception is determined significantly by considerations of the history of its public(s). I have then emphasized that notable events in the history of a public artwork's public can change that artwork's context of reception. As a consequence of those changes, an artwork may very well acquire some perlocutionary properties that the artist did not intend it to have. In this sense, I have concluded that IT and MT do not apply when considering public artworks. Though I believe that one should not treat the artist's intentions as irrelevant in public art matters, a public artwork's identity or its interpretation(s) need not be explained in terms of those intentions. ${ }^{28}$

\section{References}

AA.VV. (2012). Storm Over Statue Highlights Angst Over Indy Art. October 6, <http://www. courierpress.com/news/2012/oct/06/storm-over-statue-highlights-angst-over-indy-art/>.

Austin J.L. (1962). How to Do Things with Words. Oxford.

Bakhtin M. (1981). The Dialogic Imagination: Four Essays. Austin, TX.

Blair C., Jeppeson M.S., Pucci Jr E. (1991). Public Memorializing in Postmodernity: The Vietnam Veterans Memorial as Prototype, "Quarterly Journal of Speech" 77: 263-288.

Bourdieu P. (1977). Outline of a Theory of Practice. Cambridge, UK.

Carroll N. (1992). Art, Intention, and Conversation. [In:] G. Iseminger (ed.). Intention and Interpretation. Philadelphia.

Carroll N. (1995). Danto, Style, and Intention. "The Journal of Aesthetics and Art Criticism" 53.

Carroll N. (1997). The Intentional Fallacy: Defending Myself. "The Journal of Aesthetics and Art Criticism" 55.

Danto A. (1998). Tilted Arc and Public Art. [In:] G. Horowitz, T. Huhn (eds). The Wake of Art: Criticism, Philosophy, and the Ends of Taste. Amsterdam.

${ }^{28}$ An earlier version of this paper was presented at the 2013 IAS meeting in Krakow, Poland. I am grateful for the invitation that gave me the opportunity to exchange views on this subject. I also need to thank Joseph Margolis, Susan Feagin, Noel Carroll, and an anonymous reviewer for their helpful suggestions and comments. 
Davies D. (2004). Art as Performance. Maiden, MA, Oxford, UK.

Davies S. (2006). Authors' Intentions, Literary Interpretation, and Literary Value. "British Journal of Aesthetics" 46.

Dickie G. (2006). Intentions: Conversations and Art. "British Journal of Aesthetics" 46.

Dourish P. (2001). Where the Action Is: The Foundations of Embodied Interaction. Cambridge, MA.

Duranti A. (1986). The Audience as Co-Author: An Introduction. “Text” 6: 239-247.

Duranti A. (1993). Intentions, Self, and Responsibility: An Essay in Samoan Ethnopragmatics. [In:] J.J. Hill (ed.), Responsibility and Evidence in Oral Discourse. Cambridge, New York.

Duranti A. (ed.). (2005). A Companion to Linguistic Anthropology. Maiden, MA.

Duranti A. (ed.). (2009). Linguistic Anthropology: A Reader. Maiden, MA.

Duranti A. (2012). Anthropology and Linguistics. [In:] R. Fardon, et al. (eds.), SAGE Handbook of Social Anthropology. Los Angeles, CA, London, UK: 12-23.

Duranti A., Goodwin Ch. (eds.). (1992). Rethinking Context: Language as an Interactive Phenomenon. Cambridge, UK.

Eager E. et al (eds.). (2001). Women, Writing and the Public Sphere, 1700-1830. Cambridge.

Gadamer H.-G. (1976). Philosophical Hermeneutics. Berkeley, CA.

Gardiner M. (2004). Wild Publics and Grotesque Symposiums: Habermas and Bakhtin on Dialogue, Everyday Ltfe and the Public Sphere. [In:] N. Crossley, J.M. Roberts (eds.), After Habermas: New Perspectives on the Public Sphree. Oxford, Malden.

Goldblatt D. (2011). Taking Art Personally: Austin, Performatives and Art. "Contemporary Aesthetics" $9<$ http://www.contempaestheti.es.org/newvolume/pages/article.php?articleID « 612\& searchstr $=$ goldblatt $>$.

Goodwin Ch. (1981). Conversational Organization: Interaction Between Speakers and Hearers. New York, NY.

Grice H.P. (1957). Meaning. "Philosophical Review" 66.

Grice H.P. (1968). Utterer's Meaning, Sentence-Meaning and Word-Meaning. "Fundamentals of Language" 4.

Habermas J. (1962). Strukturwandel der Offentlichkeit. Untersuchungen zu einer Kategorie der bürgerlichen Gesellschafts. Darmstad and Neuwied.

Habermas J. (1989). The Structural Transformation of the Public Sphere: An Inquiry into a Category of Bourgeois Society. Cambridge, MA.

Hein H. (1996). What Is Public Art? Time, Place, and Meaning. "The Journal of Aesthetics and Art Criticism" 54.

Hirsch E.D. (1960). Objective Interpretation, "PMLA" 75: 463-479.

Hirsch E.D. (1966). Validity in Interpretation. New Haven.

Hirsch E.D. (1984). Meaning and Signficance Reinterpreted. "Critical Inquiry" 11.2.

Knight Ch.K. (2008). Public Art: Theory, Practice and Populism. Oxford and Maiden.

Knight Ch.K., Senie H.F. (2012). Editors' Statement: Audience Response. "Public Art Dialogue" 2.

Kochman Th. (1983). The Boundary Between Play and Nonplay in Black Verbal Dueling. "Language in Society" 12: 329-337.

Landes J.B. (1988). Women and the Public Sphere in the Age of the French Revolution. Ithaca.

Levinson J. (2011). Artworks and the Future. [In:] Music, Art, and Metaphysics: Essays in Philosophical Aesthetics. Oxford, New York, 179-214. 
Margolis J. (2010). The Cultural Space of the Arts and the Infelicities of Reductionism. New York, NY.

Mikulay J.G. (2011). Another Look at the Grand Vitesse. "Public Art Dialogue".

Mitchell W.J.T. (1992a). Introduction: Utopia and Critique. [In:] W.J.T. Mitchell (ed.), Art and the Public Sphere. Chicago and London.

Mitchell W.J.T. (1992b). The Violence of Public Art: Do the Right Thing. [In:] Art and the Public Sphere. Chicago and London.

Parsons G., Carlson A. (2008). Functional Beauty. Oxford, UK, New York, NY.

Richard M. (2008). When Truth Gives Out. Oxford, UK, New York, NY.

Rospocher M. (2012). Beyond the Public Sphere: A Historiographical Transition. [In:] M. Rospocher (ed.), Beyond the Public Sphere: Opinions, Publics, Spaces in Early Modern Europe. Bologna, Berlin.

Schegloff E.A., Sacks H. (1973). Opening Up Closings. "Semiotica" 8: 289-327.

Senie H.F. (1992). Public Art and Public Response. [In:] H.F. Senie, S.Webster (eds.), Critical Issues in Public Art: Content, Context, and Controversy. New York.

Senie H.F. (2002). The Tilted Arc Controversy: Dangerous Precedent? Minneapolis, MN.

Stecker R. (1994). Art Interpretation. "The Journal of Aesthetics and Art Criticism" 52: 193-206.

Streek J. (1980). Speech Acts in Interaction: A Critique of Searle. "Discourse Processes" 3: 133-154.

Taflinger N. (2012). Artur Silva Installs "Rock Steady Gravity Sketch" on the Avenue. Brazilian-

Born Artist Pays Homage to Hip-Hop and Jazz. "The Indianapolis Star", August 25, $<$ http://www.indystar.com/article/20120824/THINGST0D003/208250321/Artur-Silva-

installs-Rock-Steady-Gravity-Sketch-Avenue $>$.

Warner M. (2002). Publics and Counterpublics. New York.

Wilson K. (1997). Confession of a Weak Anti-intentionalist: Exposing Myself. "The Journal of Aesthetics and Art Criticism" 55.

Wittgenstein L. (1953). Philosophical. Oxford, UK.

Zuidervaart L. (2011). Art in Public: Politics, Economics, and Democratic Culture. New York. 